\title{
PERBANDINGAN REKSA DANA PENDAPATAN TETAP SYARIAH DAN REKSA DANA SAHAM SYARIAH BERDASARKAN TINGKAT PENGEMBALIANNYA PADA PERIODE JANUARI 2011- \\ DESEMBER 20141)
}

\author{
Samsidar Widiarso \\ Mahasiswa Program Studi Ekonomi Islam-Fakultas Ekonomi dan Bisnis-Universitas Airlangga \\ Email:wsamsidar@gmail.com
}

Imron Mawardi

Departemen Ekonomi Syariah-Fakultas Ekonomi dan Bisnis-Universitas Airlangga Email:ronmawardi@feb.unair,ac.id

\begin{abstract}
:
This research aims to know the comparison of the rate of return on fixed income mutual funds stock mutual funds and the Islamic Shariah from January 2011 to December 2014. The research method used is the quantitative approach. Variable used is the return value of the net assets of mutual funds, fixed income and net asset value of mutual fund shares. As for the analytical techniques used are paramatrik statistical hypothesis test using two sample is not paired and test the average difference T-Test.Based on the results of the research there is, normality test variables that are not distributed normally so do test MannWhitney on a variable with a result of 757.000 with significance value of 0.039 . Then there is a significant difference in the rate of return fixed income mutual funds stock mutual funds and the Islamic Sharia..
\end{abstract}

Keywords: rate of return, sharia fixed income funds, Sharia equity funds

\section{PENDAHULUAN}

\section{Latar Belakang}

Pasar modal merupakan pasar untuk berbagai macam instrumen kevangan jangka panjang yang bisa diperjualbelikan. Dengan adanya pasar modal maka pihak yang memiliki kelebihan dana dapat menginvestasikan dana tersebut dengan harapan memperoleh tingkat pengembalian, sebagian pihak emiten dapat memanfaatkan dana tersebut untuk kepentingan investasi tanpa harus menunggu tersedianya dana dari operasi perusahaan.

Dengan adanya pasar modal maka aktivitas perekomian akan meningkat karena pasar modal menyediakan berbagai alternatif pendanaan bagi perusahaan, sehingga dapat beroperasi dengan skala yang lebih besar, dan selanjutnya akan meningkatkan pendapatan perusahaan dan kemakmuran masyakat luas (Darmadji, 2008).

Tabungan menjanjikan keuntungan yang pasti apabila kita berinvestasi di bank, tingkat keuntungan yang dijanjikan oleh bank biasanya berkisar antara $1-4 \%$ per tahunnya, sedangkan deposito memiliki tingkat pengembalian yang lebih tinggi dibandingkan dengan tabungan. Walaupun sama-sama dipastikan mendapatkan keuntungan yang pasti setiap bulannya, akan tetapi deposito memiliki tingkat pengembalian yang lebih besar dibanding tabungan. Besaran tingkat pengembalian deposito bisa mencapai 5-9\% per tahunnya.

Dibanding dengan kedua jenis investasi diatas, terdapat jenis investasi yang lain, yaitu reksa dana. Tingkat

1) Jurnal ini merupakan bagian dari skripsi yang ditulis oleh SamsidarWidiarso, NIM: 040811637 yang diuji pada 8 Agustus 2016. 
Widiarso, et al/Jurnal Ekonomi Syariah Teori dan Terapan Vol. 4 No. 4 April 2017: 268-280; PERBANDINGAN REKSA DANA PENDAPATAN TETAP SYARIAH DAN REKSA DANA SAHAM SYARIAH BERDASARKAN TINGKAT PENGEMBALIANNYA PADA PERIODE JANUARI 2011-DESEMBER 2014

keuntungan yang lebih tinggi dibandingkan jenis investasi-investasi yang ada menjadikan reksa dana sebagai favorit para investor untuk menginvestasikan vangnya. Meskipun demikian, tidak serta merta membuat investor berani untuk menginvestasikan dananya ke jenis investasi ini, dikarenakan investor pemula banyak yang belum memahami tentang jenis-jenis reksa dana. Tingkat pengembalian reksa dana pun bervariasi berdasarkan jenisnya, terdapat jenis reksa dana yang bersifat agresif sehingga mendapatkan tingkat pengembalian yang besar, dan ada juga jenis reksa dana yang tidak agresif sehingga tingkat pengembalian yang diberikan tidak terlalu besar.

Pasar modal Indonesia dalam beberapa tahun terakhir berkembang secara dinamis. Dalam perkembangannya, pasar modal Indonesia harus bisa membuka diri terhadap perkembangan pasar modal internasional dan melakukan pembenahan diri agar standar regulasi yang ada sesuai dengan praktik kegiatan pasar modal internasional. Oleh karena itu Bapepam-lk harus menyediakan perangkat regulasi yang berstandar internasional yang dituangkan dalam berbagai bentuk peraturan perundang-undangan, termasuk didalamnya undang-undang yang menjadi acuan bagi peraturan pelaksanaan lainnya yang berkaitan dengan kegiatan pasar modal yaitu Undang-Undang Pasar Modal. Produk hukum ini mengacu kepada ketentuan standar praktik kegiatan pasar modal internasional (Yuli Muhasti, 2009).

Reksa dana konvensional

mempunyai perbedaan dengan reksa dana syariah berdasarkan definisinya.
Menurut Undang-Undang Pasar Modal No. 8 Tahun 1995 pasal 1 ayat 27 telah diberikan definisi

"Reksa Dana adalah wadah yang
dipergunakan untuk menghimpun
dana dari masyarakat pemodal untuk
selanjutnya diinvestasikan dalam
portofolio efek oleh manajer
investasi".
Dengan kata lain reksa dana merupakan wadah berinvestasi secara kolektif untuk ditempatkan dalam portofolio berdasarkan kebijakan investasi yang ditetapkan oleh fund manager atau manajer investasi. Sedangkan reksa dana syariah mengandung pengertian sebagai reksa dana yang pengelolaan dan kebijakan investasinya mengacu pada syariat Islam. Investasi yang dipilih dalam portofolionya haruslah dapat dikategorikan halal, dikatakan halal jika pihak yang menerbitkan instrumen investasi tersebut tidak melakukan usaha yang bertentangan dengan prinsip-prinsip Islam, seperti tidak melakukan riba, maysir dan gharar. Jadi, saham, obligasi dan sekuritas lainnya yang dikeluarkan perusahaan yang berhubungan dengan produksi atau penjualan minuman keras, rokok, produk mengandung babi, bisnis hiburan berbau maksiat, bisnis senjata, perjudian, pornografi dan sebagainya tidak dimasukkan ke dalam portofolio reksa dana syariah.

Baik buruknya suatu investasi tidak terlepas dari adanya faktor-faktor lain yang mempengaruhi, faktor-faktor yang diduga memiliki pengaruh terhadap net asset value (NAV) atau Nilai Aktiva Bersih (NAB) reksa dana saham syariah adalah 
Widiarso, et al/Jurnal Ekonomi Syariah Teori dan Terapan Vol. 4 No. 4 April 2017: 268-280; PERBANDINGAN REKSA DANA PENDAPATAN TETAP SYARIAH DAN REKSA DANA SAHAM SYARIAH BERDASARKAN TINGKAT PENGEMBALIANNYA PADA PERIODE JANUARI 2011-DESEMBER 2014

tingkat inflasi di dalam negeri, nilai tukar rupiah, dan BI Rate. Secara teori, faktorfaktor tersebut berkaitan dengan net asset value (NAV) reksa dana saham syariah sehingga di harapkan investor dapat menjadikannya sebagai indikator untuk mengetahui NAV/NAB per unit reksa dana saham syariah.

Bagi investor yang ingin mendapatkan tingkat pengembalian yang tinggi biasanya menginvestasikan uangnya ke jenis reksa dana saham syariah karena mempunyai tingkat pengembalian yang tertinggi dibanding dengan jenis reksa dana yang lainnya, tingkat pengembalian dari reksa dana jenis ini bisa mencapai $15 \%$ pertahun bahkan lebih jika manajer investasi dapat mengalokasikan dana nasabahnya dengan baik, akan tetapi jenis reksa dana ini sangatlah fluktuatif sehingga naik atau turunnya tingkat pengembalian yang diberikan bisa berbeda dalam setiap bulannya. Bagi seorang investor yang ingin menginvestasikan uangnya untuk jangka diatas 5 tahun biasanya menginvestasikan vangnya pada jenis reksa dana saham syariah.

Berbeda dengan reksa dana saham syariah, reksa dana campuran syariah mempunyai tingkat pengembalian yang lebih sedikit dibandingkan dengan reksa dana saham syariah dan risiko yang terjadi lebih kecil dibandingkan dengan reksa dana saham syariah. Jenis reksa dana ini dapat dilakukan oleh investor yang ingin berinvestasi dengan risiko yang lebih kecil tetapi tingkat pengembaliannya lumayan tinggi, meskipun lebih kecil dibandingkan dengan reksa dana saham syariah. Selain itu jangka waktu untuk reksa dana jenis ini berkisar 4-5 tahun.

Reksa dana pasar vang syariah memiliki tingkat pengembalian terkecil dari keempat jenis reksa dana tersebut. Besaran tingkat pengembalian dari reksa dana pasar vang hampir sama dengan tingkat pengembalian deposito. Dikarenakan memiliki tingkat pengembalian terkecil, maka risiko yang dimiliki oleh reksa dana pasar vang syariah juga sangat kecil. Biasanya investor jangka pendek lebih suka mengalokasikan dananya untuk diinvestasikan pada jenis reksa dana ini.

Dan yang terakhir adalah reksa dana pendapatan tetap syariah, reksa dana ini memiliki tingkat pengembalian diatas reksa dana pasar vang syariah tetapi lebih kecil dibanding reksa dana saham syariah dan reksa dana campuran syariah. Bisa dikatakan bahwa reksa dana pendapatan tetap syariah merupakan reksa dana jenis menengah.Setelah diketahui bahwa reksa dana saham syariah mempunyai tingkat pengembalian yang tertinggi dibanding jenis-jenis reksa dana syariah lainnya, sedangkan reksa dana pendapatan tetap syariah memiliki tingkat pengembalian menengah maka penulis ingin membandingkan tingkat pengembalian dari reksa dana saham syariah dengan reksa dana pendapatan tetap syariah agar dapat diketahui 
Widiarso, et al/Jurnal Ekonomi Syariah Teori dan Terapan Vol. 4 No. 4 April 2017: 268-280; PERBANDINGAN REKSA DANA PENDAPATAN TETAP SYARIAH DAN REKSA DANA SAHAM SYARIAH BERDASARKAN TINGKAT PENGEMBALIANNYA PADA PERIODE JANUARI 2011-DESEMBER 2014

apakah terdapat perbedaan diantara keduanya.

Berdasarkanlatarbelakang yang di uraikandiatasmakadapatdirumuskanperm asalahansebagaiberikut:

Apakah terdapat perbedaan pada tingkat pengembalian pada Reksa Dana Pendapatan Tetap Syariah dan Reksa Dana Saham Syariah?

Berdasarkanrumusanmasalahdiata s, makatujuandaripenelitianiniadalah:

Untuk mengetahui adanya perbedaan tingkat pengembalian pada Reksa Dana Pendapatan Tetap Syariah dan Reksa Dana Saham Syariah.

\section{Landasan Teori}

Dalam arti sempit, pasar modal adalah suatu pasar (tempat, gedung) yang disiapkan guna memperdagangkan saham-saham, obligasi-obligasi, dan jenis surat berharga lainnya dengan memakai jasa perantara pedagang efek (Sunariyah, 1997:4-5).

Transaksi investasi atau jual beli surat berharga di pasar modal dapat berbentuk (Sunariyah, 1997:5-6):

1. Utang berjangka (jangka pendek/panjang) merupakan salah satu bentuk pendanaan dalam suatu entitas (badan usaha) yang dilakukan dengan menerbitkan surat berharga dan dijual kepada para pemilik dana ataupun para pemodal. Dalam rangka utang jangka panjang dikenal dua macam surat berharga, yaitu:

1) Surat obligasi, merupakan pengakuan utang oleh suatu entitas (biasanya berbentuk badan usaha perseroan terbatas) dengan disertai janji memberikan imbalan bunga dengan rate tertentu.

2) Sekuritas lainnya, terdiri dari berbagai jenis sekuritas yang biasanya disebut sekuritas kredit, misalnya: waran, opsi dan future.

2. Penyertaan

Penyertaan merupakan salah satu bentuk penanaman modal dalam suatu entitas (badan usaha) yang dilakukan dengan menyetorkan sejumlah dana tertentu dengan tujuan untuk menguasai sebagian hak pemilikan atas perusahaan tersebut.

Menurut Suad Husnan (2004:3)

mendefinisikan bahwa pasar modal sebagai pasar untuk berbagi instrumen keuangan (atau sekuritas) jangka panjang yang bisa diperjualbelikan, baik dalam bentuk hutang maupun modal sendiri, baik yang diterbitkan pemerintah, public authorities, maupun perusahaan swasta.

Penjualan sekuritas berdasarkan tempat diberlakukannya jual-beli sekuritas ada beberapa macam (Sunariyah, 1997:12-14), yaitu:

1. Pasar perdana (primary market), adalah penawaran saham dari perusahaan-perusahaan yang menerbitkan saham (emiten) kepada pemodal selama waktu yang ditetapkan oleh pihak sebelum saham tersebut diperdagangkan di pasar sekunder. Pengertian tersebut menunjukkan bahwa pasar perdana merupakan pasar modal yang memperdagangkan saham-saham atau sekuritas lainnya, yang dijual untuk pertama kalinya sebelum saham tersebut dicatatkan di dalam bursa efek.

2. Pasar sekunder (secondary market), diartikan sebagai perdagangan saham setelah pasar melewati masa penawaran pada pasar perdana (primary market). Dalam pasar sekunder saham dan sekuritas lain diperjualbelikan secara luas, setelah melalui masa penjualan di pasar perdana.

3. Pasar ketiga (third market), adalah tempat perdagangan saham atau sekuritas lainnya di luar bursa (over the 
Widiarso, et al/Jurnal Ekonomi Syariah Teori dan Terapan Vol. 4 No. 4 April 2017: 268-280; PERBANDINGAN REKSA DANA PENDAPATAN TETAP SYARIAH DAN REKSA DANA SAHAM SYARIAH BERDASARKAN TINGKAT PENGEMBALIANNYA PADA PERIODE JANUARI 2011-DESEMBER 2014

counter market). Bursa paralel merupakan suatu sistem perdagangan efek yang terorganisir diluar bursa efek resmi, dalam bentuk pasar sekunder yang diatur dan dilaksanakan oleh Perserikatan Perdagangan Uang dan Efek dengan diawasi dan dibina oleh Badan Pengawas Pasar Modal.

4. Pasar keempat (fourth market), yaitu bentuk perdagangan efek antar pemodal atau dengan kata lain pengalihan saham dari satu pemegang saham ke pemegang saham lainnya tanpa melalui perantara pedagang efek.

Investasi (Sunariyah, 2003:4)

didefinisikan sebagai suatu penanaman modal untuk satu atau lebih aktiva yang dimiliki dan biasanya berjangka waktu lama dengan harapan mendapatkan keuntungan di masa-masa yang akan datang.

Dari definisi tersebut dapat di simpulkan bahwa investasi adalah komitmen atas sejumlah dana selama periode waktu tertentu untuk mendapatkan keuntungan (profit) di masa yang akan datang.

Investasi dalam pengertian kapitalis memiliki 2 makna; makna ekonomi (iqtishady) dan makna moneter (maaliy). Secara ekonomi, investasi, oleh P. Samuelson dan W. Nordhaus diartikan dengan: "Economic activity that forgoes consumption today with an eye to increasing output in future." Investasi bisa berupa tangible capital, sperti alat alat produksi, maupun intangible capital, seperti pendidikan, riset, dan kesehatan. Menurut keduanya, "there is investment only when new capital is created".
Maksudnya adalah penambahan pada tangible capital, seperti alat produksi.

Investasi dalam Islam dapat dilihat dari 3 sudut; individu, masyarakat dan agama. Bagi individu, investasi merupakan kebutuhan fitrawi, dimana setiap individu, pemilik modal (uang), selalu berkeinginan untuk menikmati kekayaan itu dalam waktu dan bidang seluas mungkin. Bukan hanya untuk pribadinya, bahkan untuk keturunannya, maka investasi merupakan jembatan bagi individu, dalam rangka memenuhi kebutuhan fitrah ini (Munir dan Jalaludin, 2006:181-182).

Istilah portofolio pertama kali diperkenalkan oleh Markowitz (1952), dimana metode meminimalisir risiko dengan melihat variasi dari aset dan mencari minimum variance portofolio setelah aset digabung membentuk sebuah portofolio. Hal lainnya yang terpenting dalam berinvestasi adalah melihat risiko terlebih dahulu untuk memaksimalkan return.

Menurut Adler HM $(2008,2)$, definisi yang diuraikan sebelumnya secara jelas disebutkan bahwa reksa dana mempunyai beberapa karakteristik. Yaitu pertama, kumpulan dan dana pemilik, dimana pemilik reksa dana adalah berbagai pihak yang menginvestasikan atau memasukkan dananya ke reksa dana dengan berbagai variasi. Artinya, investor dari reksa dana dapat perorangan dan lembaga dimana pihak tersebut melakukan investasi ke reksa 
Widiarso, et al/Jurnal Ekonomi Syariah Teori dan Terapan Vol. 4 No. 4 April 2017: 268-280; PERBANDINGAN REKSA DANA PENDAPATAN TETAP SYARIAH DAN REKSA DANA SAHAM SYARIAH BERDASARKAN TINGKAT PENGEMBALIANNYA PADA PERIODE JANUARI 2011-DESEMBER 2014

dana sesuai dengan tujuan investor tersebut.

Kedua, diinvestasikan kepada efek yang dikenal dengan instrumen investasi. Dana yang dikumpulkan dari masyarakat tersebut diinvestasikan ke dalam instrumen investasi seperti rekening koran, deposito, surat utang jangka pendek yang dikenal dengan Repurchase Agreement (REPO), Commercial Paper (CP)/ Promissory Notes (PN); surat utang jangka panjang seperti Medium Term Notes (MTN); Obligasi dan Obligasi Konversi; dan efek saham maupun ke efek yang berisiko tinggi seperti opsi, future dan sebagainya. Manajer investasi melakukan investasi pada berbagai instrumen tersebut mempunyai besaran yang berbeda-beda sesuai dengan perhitungan manajer investasi untuk mencapai tingkat pengembalian yang diharapkan.

Ketiga, reksa dana tersebut dikelola oleh manajer investasi. Manajer investasi dapat diperhatikan dari dua sisi yaitu sebagai lembaga dan sebagai perorangan. Sebagai lembaga harus mempunyai izin perusahaan untuk mengelola dana, dimana izin tersebut diperoleh dari Bapepam (Badan Pengawas Pasar Modal) bagi perusahaan yang bergerak dan berusaha di Indonesia.

Keempat, reksa dana merupakan instumen investasi jangka menengah dan panjang. Jangka menengah dan panjang merupakan refleksi dari investasi reksa dana tersebut, karena umumnya reksa dana melakukan investasi kepada instrumen investasi jangka panjang seperti Medium Term Notes, Obligasi dan saham. Dengan konsep karakteristik tersirat ini maka reksa dana tidak dapat dianggap sebagai saingan dari deposito produk perbankan tersebut. Reksa dana dianggap produk komplemen dari produk yang ditawarkan perbankan.

Kelima reksa dana merupakan produk investasi yang berisiko. Berisikonya reksa dana karena oleh instrumen investasi yang menjadi portofolio reksa dana tersebut, dan pengelola reksa dana (manajer investasi) yang bersangkutan. Berisikonya reksa dana karena harga instrumen portofolionya yang berubah setiap waktu. Bila reksa dana berisikan obligasi maka kebijakan pemerintah Bank Indonesia menaikkan tingkat bunga akan membuat harga obligasi mengalami penurunan. Manajer investasi juga bisa membuat reksa dana berisiko dengan tindakan disengaja atau tidak disengaja.

Dari sisi peraturan Bapepam, reksa dana di Indonesia dibagi dalam 4 (empat) jenis kategori (Harahap dan Pardomuan, 2003) yaitu:

1. Reksa Dana Pasar Uang didefinisikan sebagai reksa dana yang melakukan investasi $100 \%$ pada efek pasar uang. Efek pasar uang sendiri didefinisikan sebagai efek-efek hutang berjangka kurang dari satu tahun. Reksa dana pasar vang merupakan reksa dana dengan tingkat risiko paling rendah. Di lain pihak, potensi keuntungan reksa dana ini juga terbatas. Reksa dana 
Widiarso, et al/Jurnal Ekonomi Syariah Teori dan Terapan Vol. 4 No. 4 April 2017: 268-280; PERBANDINGAN REKSA DANA PENDAPATAN TETAP SYARIAH DAN REKSA DANA SAHAM SYARIAH BERDASARKAN TINGKAT PENGEMBALIANNYA

pasar vang cocok digunakan untuk investasi jangka pendek, sebagai pelengkap investasi deposito atau tabungan yang sudah ada. Tujuan investasi ini umumnya untuk perlindungan capital dan untuk menyediakan likuiditas yang tinggi, sehingga jika dibutuhkan, kita dapat mencairkannya setiap saat dengan risiko penurunan nilai investasinya yang hampir tidak ada.

2. Reksa Dana Pendapatan Tetap adalah reksa dana yang melakukan investasi sekurang-kurangnya $80 \%$ dari portofolio yang dikelolanya kedalam efek bersifat hutang. RDPT cocok untuk tujuan investasi jangka menengah dan jangka panjang (lebih dari 3 tahun) dengan risiko menengah. Pada umumnya RDPT memberikan pembagian keuntungan berupa uang tunai (dividen) yang dibayarkan secara teratur, misalnya 3 bulanan, 6 bulanan atau tahunan.

3. Reksa Dana Saham adalah reksa dana yang melakukan investasi sekurangkurangnya $80 \%$ dari portofolio yang dikelolanya kedalam efek bersifat ekuitas (saham). Efek saham umumnya memberikan hasil yang lebih tinggi berupa capital gain melalui pertumbuhan harga-harga saham, dan juga memberikan hasil berupa dividen. Investasi pada saham adalah jenis investasi jangka panjang yang sangat menjanjikan. Dengan harga-harga saham yang sangat berfluktuasi, RDS dapat memberikan potensi pertumbuhan nilai investasi yang lebih besar, demikian juga risikonya.

4. Reksa Dana Campuran adalah reksa dana yang melakukan investasi dalam efek ekuitas dan efek hutang yang perbandingannya (alokasi) tidak termasuk dalam kategori RDPT dan RDS. Melihat fleksibilitas baik dalam pemilihan jenis investasinya (saham, obligasi, deposito, atau efek lainnya) serta komposisi alokasinya, RDC dapat berorientasi ke saham, obligasi atau bahkan ke pasar vang. Dari sisi pengelolaan investasi, fleksibilitas ini dapat dimanfaatkan untuk berpindahpindah dari saham ke obligasi atau deposito, atau sebaliknya tergantung pada kondisi pasar dengan melakukan aktivitas trading, atau sering juga disebut usaha melakukan market timing.

Menurut Amalia dan Arifin (1999), reksa dana berdasarkan komposisi sekuritas yang dibentuknya dibagi menjadi reksa dana saham, reksa dana pendapatan tetap, reksa dana campuran dan reksa dana pasar vang. Reksa dana saham (common stock fund) adalah reksa dana yang komposisinya terdiri dari saham biasa perusahaan-perusahaan publik. Jenis reksa dana ini kadang juga memiliki penekanan-penekanan tertentu dari saham yang dipilih. Ada yang menekankan pada saham perusahaan yang sedang tumbuh, ada yang memilih saham kelompok industri tertentu atau bahkan saham perusahaan pada area tertentu. Reksa dana pendapatan tetap 
Widiarso, et al/Jurnal Ekonomi Syariah Teori dan Terapan Vol. 4 No. 4 April 2017: 268-280; PERBANDINGAN REKSA DANA PENDAPATAN TETAP SYARIAH DAN REKSA DANA SAHAM SYARIAH BERDASARKAN TINGKAT PENGEMBALIANNYA PADA PERIODE JANUARI 2011-DESEMBER 2014

menyusun portofolionya terdiri dari alternatif investasi yang berpendapatan tetap seperti obligasi, baik yang dikeluarkan oleh pemerintah maupun perusahaan. Reksa dana campuran menyusun portofolio berdasarkan kombinasi antara saham dan obligasi. Dan reksa dana pasar vang adalah reksa dana yang memilih pasar vang sebagai dasar penyusunan portofolionya.

Nilai Aktiva Bersih (NAB) atau disebut juga Net Asset Value (NAV) merupakan nilai pasar wajar (fair market value) suatu efek dan kekayaan lain dari reksa dana dikurangi dengan kewajiban (utang). NAB merupakan salah satu tolok ukur dalam memantau hasil dari suatu reksa dana. Nilai aktiva bersih per unit penyertaan adalah harga wajar dari portofolio suatu reksa dana setelah dikurangi biaya operasional kemudian dibagi jumlah saham/ unit penyertaan yang telah beredar (dimiliki investor) pada saat tersebut.

Rumus untuk menghitung NAB adalah sebagai berikut (Iman, 2008):

$N A B=$ (JumlahAsset-TotalKewajiban) JumlahUnitPenyertaan

Nilai wajar merupakan nilai pasar dari instrumen investasi keuangan berupa saham, obligasi, surat berharga pasar vang, serta deposito ditambah dividen saham dan kupon obligasi kemudian dikurangi biaya operasional Reksa Dana. Biaya operasional reksa dana mencakup biaya manajer investasi, biaya Bank Kustodian, dan rupa-rupa biaya reksa dana lainnya.

Return merupakan pengembalian pendapatan yang diterima dari investasi ditambah perubahan harga pasar, biasanya dinyatakan sebagai persentase dari harga pasar investasi awal (Van Horne, 1997).

Return yang diharapkan investor didapatkan setelah menanggung biaya kesempatan (opportunity cost) dan return yang terjadi (realized return). Return yang diharapkan merupakan tingkat return yang diantisipasi investor di masa mendatang. Sedangkan return yang terjadi (actual return) merupakan tingkat return yang telah diperoleh investor pada masa yang telah lalu.

\section{Metode Penelitian}

\section{Pendekatan Penelitian}

Pendekatan yang dilakukan dalam penelitian ilmiah ini adalah pendekatan kuantitatif. Penelitian ini menitikberatkan pada pengujian hipotesis, data yang digunakan harus terukur, dan akan menghasilkan kesimpulan yang dapat digeneralisasikan (Sugiyono, 1997: 10).

Pendekatan ini lebih sering berupaya mengukur suatu konsep variabel, sehingga lebih mudah dipahami secara statistik.

Menurut Arikunto dalam Anshori dan Iswati (2009: 15) penelitian kuantitatif diharuskan menggunakan angka mulai dari pengumpulan data, penafsiran data, serta penampilan hasil penelitiannya oleh karena itu peneliti dituntut memahami dan menguasai statistik sebagai alat analisis data.

Penelitian ini diambil dari data Nilai Aktiva Bersih (NAB) reksa dana syariah yang berada di dalam situs Bappepam-lk tahun 2011 sampai 2014 dan 
Widiarso, et al/Jurnal Ekonomi Syariah Teori dan Terapan Vol. 4 No. 4 April 2017: 268-280; PERBANDINGAN REKSA DANA PENDAPATAN TETAP SYARIAH DAN REKSA DANA SAHAM SYARIAH BERDASARKAN TINGKAT PENGEMBALIANNYA PADA PERIODE JANUARI 2011-DESEMBER 2014

menghasilkan kesimpulan yang dapat digeneralisasi.

\section{IdentifikasiVariabel}

Variabel yang digunakan dalam penelitian ini adalah tingkat pengembalian nilai aktiva bersih reksa dana pendapatan tetap syariah, dan tingkatpengembaliannilai aktiva bersih reksa dana saham syariah.

\section{Prosedur Pengumpulan Data}

Populasi

Populasi adalah wilayah generalisasi yang terdiri atas subyek yang mempunyai kualitas dan karakteristik tertentu yang ditetapkan peneliti untuk dipelajari dan ditarik kesimpulannya" (Anshori dan Sri, 2009:92).

Populasi dalam penelitian ini adalah sampel jenuh yaitu kelompok reksa dana pendapatan tetap syariah dan reksa dana saham syariah yang tergabung dalam reksa dana periode tahun 2011-2014.

\section{Sampel}

Penentuan sampel dalam penelitian ini menggunakan metode non probability sampling, yaitu teknik pengambilan sampel yang tidak memberi peluang/kesempatan sama bagi setiap unsur atau anggota populasi untuk dipilih menjadi sampel. Metode sampel ini meliputi sampling sistematis, kuota, aksidental, purposive, jenuh, dan snowball. Teknik yang digunakan adalah sampel jenuh, karena apabila menambah responden selanjutnya boleh dikatakan tidak lagi diperoleh tambahan informasi baru yang berarti. Penelitian ini menggunakan sampel dengan kriteria sebagai berikut:

1) Sampel yang diambil adalah tingkat pengembalian nilai aktiva bersih reksa dana pendapatan tetap syariah dan reksa dana saham syariah yang terdapat pada data Bappepam-lk tahun 2014.

2) Sampel yang diambil memiliki data historis nilai aktiva bersih selama tahun 2014.

Pengumpulan data pada penelitian ini dilakukan melalui beberapa tahap sebagai berikut:

1. Studi kepustakaan dilakukan dengan mengumpulkan data yang bersumber dari literatur, jurnal, dan penelitian terdahulu yang berhubungan dengan penelitian.

2. Pengumpulan data-data sekunder yang telah diolah dari dokumen seperti data historis perdagangan, artikel, analisis para ahli, dan sebagainya yang diperoleh dari lembaga terkait seperti Bappepam-lk, dan sumber lainnya dari internet.

\section{Teknik Analisis}

Teknik analisis dalam penelitian kuantitatif menggunakan statistik, Statistik merupakan kumpulan dari beberapa metode yang digunakan untuk menghasilkan suatu data (Anshori dan Sri, 2009:116). Statistik yang digunakan dalam penelitian ini adalah statistik paramatrik dengan menggunakan uji hipotesis dua sampel tidak berpasangan. Uji beda ratarata T-Test digunakan karena sampel yang akan di analisis bersifat tidak berhubungan atau bebas. Sampel yang dipakai adalah 
Widiarso, et al/Jurnal Ekonomi Syariah Teori dan Terapan Vol. 4 No. 4 April 2017: 268-280; PERBANDINGAN REKSA DANA PENDAPATAN TETAP SYARIAH DAN REKSA DANA SAHAM SYARIAH BERDASARKAN TINGKAT PENGEMBALIANNYA PADA PERIODE JANUARI 2011-DESEMBER 2014

tingkat pengembalian nilai aktiva bersih reksa dana pendapatan tetap syariah dan sampel yang satunya adalah total nilai aktiva bersih reksa dana saham syariah.

\section{Hasil dan Pembahasan}

\section{AnalisisHasilPenelitian}

Pada penelitian ini akan diketahui bagaimana perbandingan antara tingkat pengembalian reksa dana pendapatan tetap syariah dengan tingkat pengembalian reksa dana saham syariah. Teknik analisis yang dapat digunakan dalam mengetahui masalah tersebut adalah dengan menggunakan uji beda. Sebelum melakukan pengujian tersebut, maka terlebih dahulu data diuji apakah data berdistribusi norrmal atau tidak. Hal ini digunakan untuk menentukan uji beda apa yang akan digunakan. Berikut ini adalah hasil uji normalitas dari tingkat pengembalian reksa dana pendapatan tetap syariah dan tingkat pengembalian reksa dana saham syariah dengan menggunakan uji kolmogorov-smirnov.

Tabel 1.

Uji NormalitasTingkat Pengembalian Reksa

Dana Pendapatan Tetap Syariah dan Saham Syariah

\begin{tabular}{|l|r|r|c|}
\hline \multirow{2}{*}{ Variabel } & \multicolumn{3}{|c|}{ Kolmogorov- } \\
& \multicolumn{3}{|c|}{ Smirnov } \\
\cline { 2 - 4 } & $\begin{array}{r}\text { Stat } \\
\text { istic }\end{array}$ & $\begin{array}{r}\text { d } \\
\text { Tingkat }\end{array}$ & Sig. \\
\hline $\begin{array}{l}\text { Tingemgembalian reksa } \\
\text { dana pendapatan } \\
\text { tetap syariah }\end{array}$ & 0,0 & 4 & 0,2000 \\
\hline
\end{tabular}

\begin{tabular}{|l|r|r|r|} 
Tingkat & 0,2 & 4 & 0,0000 \\
pengembalian reksa & 59 & 5 & \\
dana saham syariah & & &
\end{tabular}

Sumber :HasilPenelitian, 2016 (diolah)

Berdasarkan Tabel 1 dapat diketahui bahwa nilai kolmogorov-smirnov yang didapatkan pada variabel tingkat pengembalian reksa dana pendapatan tetap syariah adalah sebesar 0,089 dengan nilai signifikansi sebesar 0,2000. Nilai signifikansi tersebut lebih besar dibandingkan dengan taraf signifikansi yang ditentukan yaitu 0,05. Hal ini menunjukkan variabel ngkat pengembalian reksa dana pendapatan tetap syariah berdistribusi normal.

Kemudian pada variabel tingkat pengembalian reksa dana saham syariah mempunyai nilai kolmogorov-smirnov sebesar 0,259 dengan nilai signifikansi sebesar 0,000 . Nilai signifikansi yang didapatkan tersebut lebih kecil dibandingkan dengan taraf signifikansi sebesar 0,05. Oleh karena itu menunjukkan bahwa variabel tingkat pengembalian reksa dana saham syariah tidak berdistribusi normal.

Berdasarkan hasil pengujian normalitas dengan menggunakan uji Kolmogorov Smirnov tersebut maka diketahui bahwa terdapat variabel yang berdistribusi normal dan juga terdapat variabel yang tidak berdistribusi normal sehingga asumsi untuk menggunakan pengujian parametrik tidak terpenuhi. Oleh karena itu pengujian untuk menentukan perbandingan atau perbedaan antara tingkat pengembalian 
Widiarso, et al/Jurnal Ekonomi Syariah Teori dan Terapan Vol. 4 No. 4 April 2017: 268-280; PERBANDINGAN REKSA DANA PENDAPATAN TETAP SYARIAH DAN REKSA DANA SAHAM SYARIAH BERDASARKAN TINGKAT PENGEMBALIANNYA PADA PERIODE JANUARI 2011-DESEMBER 2014

reksa dana pendapatan tetap syariah dengan tingkat pengembalian reksa dana saham syariah dilakukan menggunakan uji Mann-Whitney. Berikut ini adalah uji Mann-Whitney yang dilakukan.

Tabel 2.

Hasil Uji Mann-Whitney

\begin{tabular}{|r|r|}
\hline Mann-Whitney & Asymp. Sig. (2-tailed) \\
\hline 757,000 &, 039 \\
\hline
\end{tabular}

Sumber :HasilPenelitian, 2016 (diolah)

Berdasarkan Tabel 2 diketahui bahwa nilai Mann-Whitney yang dihasilkan adalah sebesar 757,000 dengan nilai signifikansi sebesar 0,039. Nilai signifikansi tersebut lebih kecil dibandingkan dengan taraf signfikansi yang digunakan dalam penelitian ini yaitu 0,05 . Oleh karena itu dapat diketahui bahwa terdapat perbedaan yang signifikan secara statistik antara tingkat pengembalian reksa dana pendapatan tetap syariah dengan tingkat pengembalian reksa dana saham syariah.

\section{Pembahasan}

Reksa dana syariah yang ada mempunyai jenis reksadana tersendiri, yaitu dapat berupa reksadana pendapatan tetap, campuran, dan saham. Setiap jenis reksadana tersebut mempunyai risiko dan tingkat pengembaliannya masing-masing. Aset reksadana syariah underlying merupakan jenis instrumen pasar vang dan surat berharga pasar modal saham serta obligasi yang masuk dalam kategori syariah. Oleh karena itu setiap jenis reksa dana mempunyai risiko dan tingkat pengembalian yang berbeda (Sutikno, 2009:161).

Pada penelitian ini menggunakan reksa dana pendapatan tetap syariah dan reksa dana saham untuk dianalisis perbandingan pada tingkat pengembalian yang didapatkan.

Berdasarkan hipotesis penelitian ini, diketahui bahwa Ho adalah tidak terdapat perbedaan antara tingkat pengembalian pada Reksa Dana Pendapatan Tetap Syariah dengan Reksa Dana Saham Syariah dan $\mathrm{HI}$ adalah terdapat perbedaan antara tingkat pengembalian pada Reksa Dana Pendapatan Tetap Syariah dengan Reksa Dana Saham Syariah.

Hasil analisis yang dilakukan, diketahui bahwa terdapat perbedaan antara yang signifikan antara tingkat pengembalian reksa dana pendapatan tetap syariah dengan tingkat pengembalian reksa dana saham syariah, hal tersebut dibuktikan pada Uji normalitas yang terdapat pada Tabel 1. Dikarenakan pada uji normalitas terdapat salah satu variabel yang berdistribusi tidak normal, yaitu variabel tingkat pengembalian reksa dana saham syariah. Maka peneliti tidak melanjutkan penelitian ke tahap uji Independent T-test. Peneliti melanjutkan dengan metode uji Mann-Whitney untuk mendapatkan hasil agar dapat diketahui nilai variabel tingkat pengembalian reksa dana saham syariah.

Hasil dari uji Mann-Whitney untuk variabel tingkat pengembalian reksa dana saham syariah dapat diketahui dari 
Widiarso, et al/Jurnal Ekonomi Syariah Teori dan Terapan Vol. 4 No. 4 April 2017: 268-280; PERBANDINGAN REKSA DANA PENDAPATAN TETAP SYARIAH DAN REKSA DANA SAHAM SYARIAH BERDASARKAN TINGKAT PENGEMBALIANNYA PADA PERIODE JANUARI 2011-DESEMBER 2014

Tabel 2, yang menyatakan bahwa nilai Mann-Whitney yang dihasilkan adalah sebesar 757,000 dengan nilai signifikansi sebesar 0,039. Nilai signifikansi tersebut lebih kecil dibandingkan dengan taraf signfikansi yang digunakan dalam penelitian ini yaitu 0,05 . Oleh karena itu dapat diketahui bahwa terdapat perbedaan yang signifikan secara statistik antara tingkat pengembalian reksa dana pendapatan tetap syariah dengan tingkat pengembalian reksa dana saham syariah.

Kemudian pada hasil deskriptif yang telah dipaparkan sebelumnya diketahui bahwa tingkat pengembalian reksa dana saham syariah mempunyai nilai rata-rata yang lebih tinggi dibandingkan tingkat pengembalian reksa dana pendapatan tetap syariah sehingga menunjukkan adanya risiko yang lebih tinggi pula dibandingkan dengan tingkat pengembalian reksa dana pendapatan tetap syariah.

Hal ini sejalan dengan Sutikno

(2009:161) yang menyatakan bahwa:

reksadana saham secara umum berisiko tinggi sehingga potensi tingkat pengembaliannya juga tinggi. Hal ini disebabkan karena underlying aset yang digunakan adalah efek saham. Oleh karena itu diketahui bahwa terdapat perbedaan antara reksa dana pendapatan tetap syariah dengan tingkat pengembalian reksa dana saham syariah baik dalam tingkat pengembalian dan risiko yang ditanggung.

\section{SIMPULAN}

Kesimpulan yang didapatkan berdasarkan hasil analisis yang telah dilakukan adalah benarbahwa terdapat perbedaan yang signifikan antara tingkatpengembalianreksa dana pendapatan tetap syariah dengan tingkat pengembalian reksa dana saham syariahselamatahunperiode 2011 sampaidengan 2014. Tingkat pengembalian reksa dana saham syariah mempunyai nilai yang lebih tinggi dibandingkan dengan tingkat pengembalian reksa dana pendapatan tetap syariah. Dan ketikasuatureksa dana mempunyaitingkatpengembalian yang lebihtinggidibandingdenganjenisreksa dana lainnya, makarisiko yang bisaterjadi juga menjadilebihbesar.

\section{DAFTAR PUSTAKA}

Agus Sartono, 1998, Manajemen Keuangan, Edisi Ketiga, Penerbit BPFE, Yogyakarta.

Amalia, Dewi dan Zaenal Arifin. 1999. Perbandingan Kinerja Reksa Dana ; Periode Sebelum Krisis dan Periode Krisis. Yogyakarta : Sinergi UII, Vol. 2 dan No. 1.

Anshori, Muslich, dan Iswati, Sri. 2009. Buku Ajar Metodologi Penelitian Kuantitatif, Edisi Pertama, Surabaya : Airlangga University Press.

Antonio, M. Syafi'i. 2001. Bank Syariah : Dari Teori ke Praktik. Jakarta : Gema Insani.

Copeland, Thomas E., \& J. Fred Weston. 1992. Financial Theory And Corporate Policy, $5^{\text {th }}$ Ed, Addison-Wesley Publishing Company, Inc, USA.

Darmadji, Tjiptono dan Hendi M. Fakhrudin. 2008. Pasar Modal di Indonesia: Pendekatan Tanya Jawab (Edisi 2), Jakarta : Salemba Empat.

Ghufron, Sofiyani, dkk. 2005. Investasi Halal di Reksa Dana Syariah, Jakarta: Renaisan.

Harahap, Sofyan S. \& Pardomuan Pane, 2003,"Analisis Perbandingan Kinerja Reksa dana Syariah Terhadap Reksa dana Konvensional (Reksa dana 
Widiarso, et al/Jurnal Ekonomi Syariah Teori dan Terapan Vol. 4 No. 4 April 2017: 268-280; PERBANDINGAN REKSA DANA PENDAPATAN TETAP SYARIAH DAN REKSA DANA SAHAM SYARIAH BERDASARKAN TINGKAT PENGEMBALIANNYA PADA PERIODE JANUARI 2011 -DESEMBER 2014

Mawar) Tahun 1997-2001"Media Riset Bisnis \& Manajemen, volume 3 no 3.

Hassan, M.K. dan Eric Girard. 2005. Faith_based Ethical Investing: The Case of ow Jones Islamic Index. Paper in Proceedings of Fifth Harvard University Forum On Islamic Finance, Harvard University.

Haymans M, Adler. 2008. Reksa Dana Investasiku. Jakarta: PT. Gramedia.

Ibad, Akromul dan Adrianus Adhidarma. 2010. Evaluasi Kinerja Reksa Dana Saham Di Indonesia Menurut Metode Sharpe, Treynor dan Jensen serta Perbandingan Return Reksa Dana Saham Dengan LQ45 Periode Januari 2009 - Juni 2010. Jakarta : Institut Bisnis dan Informatika Indonesia.

Iman, $\quad$ Nofie. 2008. PanduanSingkatdanPraktisMemulailnve stasiReksadana. Jakarta: PT.Elex Media Komputindo.

Markowitz, Harry M. 1952. Portofolio Selection. Journal of Finance

Muhasti, Yuli. 2009. Prinsip Transparansi Pada Pembagian Keuntungan Efek Syariah Sukuk Mudharabah Di Pasar Modal Indonesia. Jakarta : Universitas Indonesia.

Munir, Misbahul dan Djalaludin, A. 2006. Ekonomi Qur'ani: Doktrin Reformasi Ekonomi dalam AI Qur'an, Malang : UIN Malang Press

Pratomo, Eko Priyo, Ubaidillah Nugraha. 2009. Reksa Dana Solusi Perencanaan Investasi di Era Modern, Edisi Revisi, Jakarta : PT. Gramedia Pustakan Utama.

Ratnawati, Vince dan Ningrum Khairani. 2012. Perbandingan Kinerja Reksa Dana Syariah dan Reksa Dana Konvensional. Jurnal Akuntansi, Vol. 1 No. 1. Riau: Universitas Riau.

Sakti, Ali. 2007. Sistem Ekonomi Islam: Jawaban atas Kekacauan Ekonomi Modern. Jakarta: Paradigma \& Aqsa Publishing

Samsul, Mohammad. 2006. Pasar Modal dan Manajemen Portofolio, Jakarta: Erlangga.

Samuelson, Paul A. dan William D. Nordhaus, 2004. Ilmu Makroekonomi. Edisi Ketujuh Belas. Jakarta: PT. Gramedia Global Edukasi.

Santoso,S. 2010.StatistikMultivariatKonsepdanAplik asidengan SPSS. Jakarta: PT.Elex Media Komputindo.

Sharpe, J William, et, al, 1997, Investasi, Jilid 2 (terjemahan), PT. Prenhallindo, Jakarta.

Siagian, D,dan Sugiarto, 2006, Metode Statistika, Gramedia Pustaka Utama, Jakarta

Sitompul, Asril, 2011 . Pasar Modal:

Penawaran Umum dan

Permasalahannya dilengkapi Dengan Undang-Undang Nomor 8 Tahun 1995 Tentang Pasar Modal dan

Penjelasannya (Cetakan ke-4), Jakarta : Citra Aditya Bakti.

Soemintra, Andri. 2009. Bank dan Lembaga Kevangan Syariah. Medan, Prenada Media.

Suad Husnan \& Pudjiastuti, Enny. 2004, Dasar-dasar Manajemen Kevangan. Yogyakarta: UPP AMP YKPM.

Sugiyono,1997, StatistikaUntukPenelitian, Bandung :Alfabeta

Sunariyah. 1997. Pengantar Pengetahuan Pasar Modal, Yogyakarta : UPP-AMP YPKN.

Sunariyah. 2000. Pengantar Pengetahuan Pasar Modal, Yogyakarta : UPP-AMP YPKN.

- 2003. Pengantar Pengetahuan Pasar Modal, edisi ke tiga, Yogyakarta: UPP-AMP YKPN.

- 2004. Pengantar Pengetahuan Pasar Modal, edisi ke empat, Yogyakarta : UPP-AMP YKPN.

Sutikno, M. Sobri, 2009. Belajar dan Pembelajaran. Bandung: Prospect.

Van Horne, James C. (1997). PrinsipprinsipManajemen Keuangan, Jakarta: Salemba Empat.

Van Horne, James C. dan John $M$ Wachowicz, Jr. 2012. Prinsip - Prinsip Manajemen Kevangan (Edisi 13). Jakarta: Salemba Empat.

Yazir, Abdul Gani, dan Suhardi. 2012. Analisis Perbandingan Resiko Dan Tingkat Pengembalian Reksa Dana Syariah Dan Reksa Dana Konvensional. Journal Accounting : Fakultas Ekonomi. Universitas Bangka Belitung.

Yusuf, Muhammad dan Wiroso. 2011 Bisnis Syariah, Jakarta: Penerbit Mitra Wacana Media. 